\title{
3.3 Умови формування та розвитку музичної культури школярів у процесі навчання
}

Учитель музичного мистецтва перед тим як приступити до дослідження рівня розвитку музичної культури школярів підліткового віку, перш за все, повинен врахувати особливості, які притаманні дітям даної вікової категорії. Зазвичай, оцінюючи підлітка просто зі сторони, буває доволі непросто дізнатися про його смаки, уподобання, схильності. Проте уважний та досвідчений вчитель розуміє, що те, що знаходиться у дитини в глибині душі, i те, який у неї внутрішній світ досить часто проявляє себе зовні в таких виявах як посмішка, погляд, голосова інтонація. Сказати про людину, що вона є духовно багатою можна у тому випадку, коли ії вчинки збігаються зі словами і доводять наявність у неї особливого внутрішнього світу, який прикрашений зовні проявами доброти, щирості і глибини. У такий же спосіб нам вдається визначити чиюсь внутрішню порожнечу і духовну убогість. Це, у переважній більшості випадків, відбувається тоді, коли неозброєним оком видно, що людина живе лише практичними і матеріальними інтересами.

Проте, перш за все необхідно враховувати незаперечні моменти, що «... підлітковий період - це лише етап, який характеризує формування особистості, $\mathrm{i}$ тому, очевидно, в жодному разі не можна впевнено і переконливо вважати учня свідомо «духовно нерозвиненим», «мало емоційним» і т. д.» [240, с.23]. Також, учитель музичного мистецтва повинен пам'ятати, що в житті кожної дитини, а особливо дитини-підлітка, отримують свого розвитку дві течії. «Одна із них видима - це те, що відбувається з дитиною зовні, зовнішні події; інша - яка є непомітною і незрозумілою сторонньому недосвідченому погляду - це те, що насичене потаємними думками, глибинними переживаннями, пошуками духовного начала, і свого власного «Я». Доволі часто саме у цьому зосереджено основний зміст людського буття» [240, с.23].

Крім усього зазначеного зауважимо, що для учителя музичного мистецтва важливо знати, що взаємовідносини в колективі дітей підліткового і юнацького 
віку вибудовуються на основі суперечливої взаємодії двох потреб: відокремлення від усіх, занурення у свій внутрішній світ і афіліації - потреби у приналежності, долучення в якусь групу чи спільноту. Найчастіше відокремлення виявляється у прагненні до незалежності від контролю батьків і вчителів. Проте, воно діє також і в стосунках з особами однієї вікової категорії.

У підлітковому віці зростає потреба не лише в соціальній автономії, а також і в автономії просторовій, територіальній, в дотриманні дистанції та обмеженні втручання у свій особистий простір. У перехідному віці змінюється трактування змісту таких понять, як «самотність» і «усамітнення». Підлітки намагаються наповнити ці значення психологічним змістом, водночас приписуючи їм не лише негативний, а також і позитивний сенс і цінність. Деякі науковці вважають, що від підліткового віку до юнацького позитивне значення перебування на самоті, усамітнення поступово зростає, а його негативний сенс - поступово зменшується і нівелюється.

Спостереження доводять, що чим більш самостійною і цілеспрямованою є молода людина, тим сильнішою буде у неї бажання і потреба перебувати на одинці. Проте, на думку багатьох науковців в галузі педагогіки та психології, у молодої людини окрім умиротвореного та спокійного усамітнення трапляється також і напружена і болісна самотність. Цей стан супроводжується тугою, ізоляцією духовною і душевною, почуттям незадоволеної людської близькості, потреби у спілкуванні. Згідно результатів масових опитувань у 1990-1991 роках діти підліткового віку і юнаки почувають себе самотніми і незрозумілими значно частіше, аніж люди старшого віку.

Відчуття самотності та неприкаяності, що пов’язані з віковими труднощами становлення особистості, саме і породжують у підлітків неймовірну спрагу до спілкування з однолітками в певних групах чи угрупуваннях, в товаристві яких знаходять чи мають надію знайти те, чим не можуть їх задовольнити старші, а саме спонтанність, порятунок від нудьги, емоційне тепло, визнання власної значущості. 
Спілкування є провідною діяльністю дітей підліткового віку, враховуючи нездоланну потребу підлітка у спілкуванні. У багатьох дітей ця потреба перетворюється в стадне почуття, яке неможливо подолати, і тоді вони не можуть не лише дня, але й години пробути за межами свого чи будь-якого іншого товариства. Вважається, що особливо яскраво вираженою і сильною така потреба $\epsilon$ у хлопчиків.

«При зовнішній схожості контурів соціальної поведінки глибинні мотиви, що ховаються за юнацькою потребою в афіліації, насправді є індивідуальними і різноманітними. Адже, один шукає в товаристві однолітків підкріплення відчуття самоповаги, визнання своєї цінності і неповторності. Для іншого важливе почуття емоційної неподільності і співпричетності з групою. Третій у своєму оточенні черпає досі відсутню інформацію і оволодіває комунікативними навичками. Четвертий прагне задовольнити свою потребу домінувати над іншими, брати правління і керування у свої руки. У переважній більшості випадків ці мотиви переплітаються і не сприймаються на свідомому рівні» [241, c.34].

Однією з типових рис підліткових груп є те, що вони палко боронячи їх незалежність від старших, у той же час мають зовсім некритичне ставлення до вчинків і думок власної групи та іiі лідерів. «Незміцніле, дифузне «Я» має потребу в сильному «Ми», яке, в свою чергу, затверджується на противагу якимсь «Вони». Причому все це повинно бути у доволі грубій формі і показово» [242, c.87].

Щире бажання і прагнення бути «як усі» (а «усі»- це виключно «свої») отримує свого поширення на одяг, естетичні смаки, включаючи уподобання у стилі поведінки, а також спільні музичні смаки.

У цьому виникає неабияке протиріччя, яке може хвилювати підлітків - це той момент, коли індивідуальні прояви затверджуються через однаковість. Ця однаковість, проте, старанно підтримується, і тому, хто наважується кинути їй виклик, доводиться протистояти усій груповій системі і витримувати нелегку боротьбу за своє власне, індивідуальне і неповторне «Я». 
Дослідження даної проблеми показують, що вчителі подекуди надають неадекватні оцінки, які стосуються музичних пристрастей підлітків. Доволі часто дитина може говорити про те, що вона слухає і любить тільки якусь типову сучасну популярну музику, щоб раптом не стати «немодним», «не таким, як усі», «дивним» і т. п. У такому випадку думка однолітків переважно є більш значимою для підлітка, аніж думка дорослого, незважаючи навіть на те, що взаємини і спілкування між учителем музичного мистецтва і школярем підліткового віку складаються у конструктивному руслі, і є довірливими.

Невиважений погляд учителя, неадекватна оцінка рівня музичної культури підлітка, не враховуючи його вікові особливості, які є природними і властивими для даного (перехідного) періоду розвитку особистості, можуть у подальшому призвести у вихованні та навчанні до суттєвих помилок.

Також, варто зазначити, що доволі часто в самому класі утворюються вікові угрупування, які, насамперед, задовольняють потребу їх учасників у вільному спілкуванні, яке не контролюється батьками і вчителями.

Згідно результатів багатьох спостережень доведено, що вільне спілкування - це не лише спосіб проведення вільного від навчання часу (слухання музики, спільне відвідування танцювальних заходів, концертів тощо), але й (можливо, перш за все!) засіб самовираження, встановлення контактів з новими людьми, 3 яких поступово викристалізовується щось своє індивідуальне. На початкових стадіях юнацьке спілкування є неминуче екстенсивним, яке вимагає доволі частих ситуативних змін і широкого кола учасників. Належність підлітка до групи, яка розділяє ті чи інші музичні уподобання, підвищує його впевненість у собі i додає додаткові імпульси та можливості для самоствердження i самореалізації.

Проаналізувавши міжособистісні відносини школярів підліткового віку в колективі, учитель музичного мистецтва має змогу розставити правильні пріоритети стосовно питання формування музичної культури учнів, враховуючи усю складну систему зв'язків, які з'являються у підростаючої особистості 3 оточуючим ï зовнішнім світом. Для підлітків спілкування з собі рівними - це 
необхідний обмін різноманітними ідеями, уявленнями, інтересами, почуттями, настроями і т. д.

При формуванні музичної культури школяра особливо важливими є дві проблеми. Першою з них вважаємо пошук вдалих і адекватних методичних засобів, які дозволяють 3 високою ймовірністю встановити рівень музичної культури школяра підліткового віку, який надає підстави для ефективної роботи 3 метою подальшого розвитку музичної культури учня. Побудова системи методик, які були б максимально придатними для визначення та вивчення рівня розвитку музичної культури школярів-підлітків, на сучасному етапі вивчення даної проблеми залишається все ще доволі складним завданням, яке потребує поглибленого вивчення.

Друга проблема, яка є не менш важливою - це більш конкретний і повний опис змін видимих, які помітні неозброєним оком, і які відбуваються 3 підлітками, що брали участь в процесі експерименту під час проведення спеціальної роботи з розвитку музичної культури. Проаналізувавши відповідну літературу можемо зробити висновок, що результати зазначеної роботи до цього часу не узагальнені; саме тому для дослідника особливий інтерес представляють дані результати процесу розвитку музичної культури школярів підліткового віку.

Підсумовуючи зазначимо, що виокремлюючи проблему формування i розвитку музичної культури школяра-підлітка як самостійного розділу в загальному дослідженні музичної культури учня має вагоме методологічне значення, яке є важливим як для вікової, так і для музичної психології. Певні психолого-педагогічні умови, які існують при формуванні музичної культури школяра підліткового віку, пов'язані, насамперед, із особливостями, які стосуються віку та індивідуальних рис дитини як особистості. Окрім того, сучасна ситуація, яка створилась в нашому суспільстві, на жаль, ускладнює процес формування музичної культури підлітка. Адже сформоване істотне роз'єднання різноманітних музичних напрямків, яке призводить до досить чіткого поділу загальної музичної продукції на легку - «естрадну» і справжню «класичну» музику, представляє неабиякі труднощі при здійсненні роботи по 
формуванню та розвитку музичної культури, яка проводиться в загальноосвітній школі.

Загалом, проблема розвитку музичної культури учня в загальноосвітній школі, яка є доволі новою в структурі психологічно-педагогічних знань, надає стимул для поглибленої праці над певними напрямками з метою переосмислення багатьох моментів, які вже було накопичено у сфері музичної психології та психології дітей підліткового віку. Адже ця проблема та іiі компетентне вирішення представляють собою новий підхід до питань всебічного розвитку дитини загалом.

Варто зазначити, що у закладах освіти навчально-виховний процес налаштований відповідно до можливостей, нахилів та інтересів індивідуальних задатків кожного учня, їх особливостей та вікових психологічних і фізіологічних розбіжностей. Цей процес наповнений системою педагогічних методик i технологій, взаємопов’ язаних між собою, завдяки яким стає більш ширший вибір змісту, засобів і форм навчання учнів.

Багато науковців у своїх дослідженнях виокремлюють три основні педагогічні завдання, реалізація яких відображається у діяльнісно-практичному до музичного мистецтва завданні, визначають різні межі долучення особистості до самого процесу осягнення музичної культури.

Завданням першим $є$ формування чуттєвого ставлення до музики спираючись на їі сприйняття. Це означає, що школярам потрібно розвивати стан чуттєвого відгуку на музику, їх емоційного проникнення в сферу музичних образів; намагатись пробудити щире бажання до прослуховування і виконання музики. Якщо братись за вирішення цього завдання, обов'язковою умовою буде врахування специфіки музичного мистецтва, яке є емоційним по своїй природі.

Другим завданням буде спрямування школяра на те, щоб він ставився до музики свідомо. Для учня важливим моментом буде набуття досвіду сприйняття творів цілісно; уміння набуті музичні знання застосовувати; характер музичних композицій не лише відчувати, а також і розуміти логіку розвитку даних творів. 
Ці два завдання знаходять свою реалізацію у єдності, адже усвідомлене відношення до музики формується на грунті досвіду ії образного і емоційного сприймання.

Третім педагогічним завданням $\epsilon$ процес формування діяльніснопрактичного ставлення до музики під час іiі виконання. Вирішення цього завдання спрямовано на формування музичної культури, яка має безпосередній зв'язок з розвитком уявлень музично-слухових, а також виконавських умінь i навичок.

Усі ці три завдання перебувають у тісному взаємозв'язку в практичній діяльності у процесі музичного навчання.

Для учителя їх усвідомлення стає базою, грунтом 3 метою виявлення вихідного рівня учнівського музичного досвіду, також фіксації проміжного ступеня і результатів формування музичної культури адаптованих до навчальних умов у позашкільних спеціалізованих закладах освіти.

Отже, базуючись на наукових здобутках робимо наступний висновок про навчання учнів, яке відбувається у напрямах, що взаємопов'язані між собою:

$$
\text { сфера емоцій - розвивається завдяки розширенню кола асоціацій }
$$
школяра, чуттєвого переживання образного змісту музичних творів, а також суджень естетичних;

сфера інтелекту - розвивається завдяки накопиченню музичнотеоретичних знань, а також осягненню музичних композицій, які $\epsilon$ різноманітними за жанрами;

сфера виконавства - розвивається через практику застосування знань, умінь і навичок у діяльності музично-інтерпретаційній.

Наука психологія розглядає це питання 3 урахуванням фізіологічних розробок, які є пов'язані з проблемою розвитку сфери емоційної, здібностей музичних, також виконавського апарату музиканта, механізмами творчого процесу та рухової діяльності.

Так, у музичній психології декларується поняття, що психічні можливості школярів бажано розглядати з урахуванням потенціалу їх розвитку і тих вимог, 
які пред’являються до результатів педагогічного процесу школою. У тому випадку, якщо мета навчання музики буде включати соціальні вимоги, а також враховувати особливості віку учнів, тенденції їх розвитку, то воно (музичне навчання) не лише випереджатиме музичний розвиток школяра, а й надасть йому певної цілеспрямованості.

Проте, обгрунтовуючи проблему психічного розвитку учнів 3 сучасних позицій сьогодення, науковці намагаються враховувати реальні умови, в яких живе і перебуває суспільство, а також розвивається школа сучасності. Дані умови трактуються як можливості розвитку особистості у психічному напрямку. Науковці підкреслюють як значимість соціального досвіду учня для формування музичної культури, так і роль змісту музики, який виявляє життєві ситуації, події і враження.

Дослідження науковців-психологів у галузі музичної освіти засвідчили інтелектуальні якості школяра сьогодення посеред його психічних особливостей. Сьогодні ні для кого не є секретом, що вже школярі молодшого шкільного віку володіють таким рівнем інтелектуальних можливостей, які ще на початковому етапі навчання дозволяють їм засвоювати основи наукових знань.

Психологи сьогодення у музичній сфері визнають, що музичний розвиток школяра $\epsilon$ процесом доволі складним i багатогранним. Однією 3 його найважливіших граней є та, яка пов’язана із розвитком спеціальних здібностей учня у комплексі: це стосується розвитку музичного слуху, музичної пам'яті, а також почуття музичного ритму. Проте, звичайно ж, музичний розвиток учня не може обмежуватись лише розвитком цих спеціальних здібностей. Доволі важливими є також і ті перетворення, внутрішні зміни, які відбуваються i фіксуються у його художній свідомості, а також музичному мисленні.

Діяльність людини, і це є загальновідомим фактом, пов’язана безпосередньо iз мисленням, і у переважні більшості випадків в своїй основі містить знання про предмет та засновується на поняттях про цей предмет. Інтелектуальних проявів не може бути за межами таких знань. Розум людини розвивається лише у іï діяльності та справжніх знаннях. 
Ця дидактична аксіома залишається актуальною і у специфічній сфері музичного мислення. Тут також необхідне знання матеріалу, певний багаж знань, який є необхідною складовою будь-якої діяльності у духовній сфері.

Процес формування і розвитку музичного інтелекту відбувається 3 поповненням досвіду власного. Це (здобуття цієї якості) іде шляхом від незнання до знання, згодом від знань нижчого гатунку до знань глибших. «Знати музичну літературу, тобто музичні твори у найбільшій кількості» - саме таке визначення надає передова музична педагогіка стосовно питань становлення та розвитку учнівської музичної свідомості [243].

Отже, якщо вважати, що розвинутий музичний інтелект з'являється завдяки накопиченню знань, їх асиміляції переробки, то можемо зробити наступні умовиводи: чим більш різноманітними і широкими будуть музичні знання (як загальні, так і спеціальні) учня, тим глибшим і більш широким буде його музичний тезаурус, i, як наслідок, більш розвинутою буде також і його музична загальна культура.

Зазначимо, що знання і розуміння музичного матеріалу, який включає в себе музичні явища, базові закономірності музичної мови, $\epsilon$ обов'язковою передумовою музичного мислення. Проте, знання про музику не лише виступають трампліном для тих чи інших мислячих операцій, але й формують їх, у такий спосіб визначаючи зміст і структуру. Знання, здобуті під час навчання, долучаються у природний спосіб до процесу музичного мислення, таким чином підіймаючи його на вищий та якісно новий рівень. Варто зазначити, що завдяки цьому стають доступними можливості, які сприятимуть засвоєнню знань, які будуть якісно новими і глибшими.

Тому, важливо, щоб на початковому етапі навчання знання були наче орієнтирами, які сприяють залученню у процес засвоєння музичної композиції учнями їх життєвого досвіду. Згодом, ці знання стануть основою, на якій буде базуватись пізнавальна діяльність дитини.

Таким чином, вектори, які впливають на формування музичної культури в учнів молодших класів та школярів-підлітків, є розвитком (у комплексі) якостей 
як особистісних, так і творчих здібностей, умінь та виконавських навичок, формування свідомості духовного та естетичного смаку, що в результаті сприятиме забезпеченню творчої самореалізації, яка зможе отримати свій розвиток в умовах діяльності, пов'язаної з музикою. 